Електронне наукове фахове видання "Ефективна економіка" включено до переліку наукових фахових видань України з питань економіки

(Категорія «Б», Наказ Міністерства освіти і науки України від 11.07.2019 № 975) www. economy.nayka.com.ua | № 8, 2020|27.08.2020 p.

DOI: $\underline{10.32702 / 2307-2105-2020.8 .5}$

UDC 336.743

\title{
P. Nikiforov
}

Doctor of Economic Sciences, Professor,

Yuriy Fedkovych Chernivtsi National University

ORCID ID: 0000-0003-4860-0139

\section{Babukh}

PhD in Economics, Associate Professor,

Yuriy Fedkovych Chernivtsi National University

ORCID ID: 0000-0001-8274-5716

Ye. Venher

PhD in Economics, Associate Professor,

Yuriy Fedkovych Chernivtsi National University

ORCID ID: 0000-0003-0350-1284

\section{FINTECH SERVICES MARKET IN UKRAINE: CURRENT SITUATION, PROBLEMS AND PROSPECTS}

\author{
П. О. Нікіфоров, \\ д. е. н., професор, завідувач кафери фінансів і кредиту, \\ Чернівецький начіональний університет імені Юрія Федьковича \\ I. Б. Бабух, \\ к. е. н., доцент кафедри маркетингу, інновацій та регіонального розвитку, \\ Чернівецький національний університет імені Юрія Федьковича \\ C. I. Венгер, \\ к. е. н., в.о. дочента кафедри маркетингу, інновачій та регіонального розвитку, \\ Чернівецький національний університет імені Юрія Федьковича

\section{РИНОК ФІНТЕХ ПОСЛУГ В УКРАЇНІ: СУЧАСНИЙ СТАН, ПРОБЛЕМИ І ПЕРСПЕКТИВИ}

In a globalized world there are radical changes in the construction of national financial systems, their organization and functioning under the influence of technological and financial innovations. Today, Fintech is the biggest driver of essentially revolutionary changes in financial systems at both the national and global levels.

Ukraine does not stand aside from these processes, the state has some achievements, but according to experts, it lags behind developed markets, and therefore it is necessary to make up for lost. Most Fintech startups in Ukraine depend on equity in the absence of a functioning capital market. The infrastructure of electronic financial services remains imperfect. It is essential to change outdated legislation to promote a favorable business environment. The Ukrainian regulator should also promote the development of regulatory 'sandboxes' so that Fintech companies can use this tool. The classical banking system in 'connections' with the Fintech industry should be more active in digital multichannel banking, use artificial intelligence in its operations, do big data analytics based on artificial intelligence, use 'cloud' infrastructure. 
As for Ukrainian Fintech companies, their unique collective image looks like they are focused on the European market, have no investment from banks, focused on the B2B service model, are self-financed, top management has experience in traditional financial services, operates more than 3 years and still in development. Services are dominated by card payments and other types of payments. Competition in the market is insignificant due to the small number of Fintech companies. Ukrainian banks, in turn, do not have shares in the capital of third-party Fintech companies, have limited experience and understanding of the Fintech industry at the board level, but have specialists responsible for working with third-party software developers.

There is no full-fledged interaction between banks and Fintech companies in Ukraine, although it is necessary for the further development of the financial services market, as currently market growth is less dependent on competition and more on raising awareness of the problems and technologies that can solve these problems.

В глобалізованому світі відбуваються кардинальні зміни у побудові начіональних фінансових систем, їх організації та функиіонуванні під впливом технологічних $і$ власне фінансових новацій. Сьогодні саме FinTech виступає найбільшим драйвером по суті револючійних змін у фінансових системах і на національному, і на глобальному рівнях.

Україна не стоїть осторонь цих процесів, вона має певні напрацювання, проте за оцінками експертів вона відстає від розвинутих ринків, а тому потрібно надолужувати втрачене. Більшість FinTech стартапів в Україні залежать від власного капіталу за відсутності функиіонуючого ринку капіталу. Інфраструктура електронних фінансових послуг залишається недосконалою. Вкрай необхідно змінювати застаріле законодавство, щзоб стимулювати сприятливе бізнес-середовище. Українському регулятору також варто сприяти розвитку регуляторних «пісочниць», щэоб FinTech компанії могли користуватись циим інструментом. Класична банківська система у «зв'язках» з FinTесh галуззю повинна більш активно займатись цифрровим багатоканальним банкінгом, використовувати штучний інтелект у своїх операціях, робити аналітику великих даних на основі штучного інтелекту, використовувати «хмарну» інфраструктуру.

Щодо українських FinTech компаній, то їх своєрідний збірний образ виглядає так, що вони зосереджені на європейському ринку, не мають інвестииій від банків, орієнтовані на модель В2В надання послуг, фінансуються самостійно, топ-менеджмент має досвід у традиційних фінансових послугах, функиіонує більш ніж 3 роки та все ще в стані розвитку. Серед послуг домінують карткові платежі та інші види платежів. Конкуренція на ринку є незначною внаслідок невеликої кількості FinTech компаній. Українські банки в свою чергу, не мають часток в капіталі сторонніх FinTech компаній, мають обмежений досвід та розуміння FinTech галузі на рівні правління, проте мають в штаті фахівців, відповідальних за співпрацฺю зі сторонніми розробниками програмного забезпечення.

Повноцінної взаємодії між банками та FinTесh компаніями в Украӥні немає, хоча вона необхідна для подальшого розвитку ринку фінансових послуг, адже наразі зростання ринку менше залежить від конкуренції та більще - від підвищення обізнаності 3 проблемами та технологіями, які можуть иј проблеми розв'язати.

Keywords: financial system; financial technologies; Fintech companies; Fintech market; Fintech sector; commercial banks; Ukrainian Fintech catalog; business models of financial services.

Ключові слова: фінансова система; фінансові технологї; Fintech компанї; Fintechринок; Fintech-сектор; комериійні банки; украйнський Fintech-каталог; бізнес-моделі фінансових послуг.

Formulation of the problem in generally and related issues, which are important in scientific and practical tasks. The financial system created by the developed world over the last half century allows these 
countries to both withstand any crisis and remain economic leaders for the foreseeable future. In our opinion, the main factors of this process are technological and financial revolutions that began in the developed world in the 70s of the XXth century and bring their results today.

Aware of the economic realities of the world in 2020 as a result of the coronavirus pandemic, we see that in a few months (March-June) the US, EU, UK, Japan mobilized to support their economies about 7 trillion US dollars, or more than $10 \%$ of total GDP of these countries. The vast majority of this money was actually 'painted', artificially created and thrown into the economy by the government issuing debt securities that were bought out by central banks. At the same time, such actions in macroeconomic terms did not provoke negative processes (rising inflation, budget deficit, etc.), but significantly stabilized the stock and currency markets, increased the national wealth of these countries more than their debt. Let us also recall the situation after the global crisis of 2008-2009, when in response to this crisis, for the first time in the Western world, only large-scale borrowings were made, mostly covered by central banks. Waves of 'quantitative easing' followed one another, the EU did not lag behind the United States, and without serious losses for the euro area.

At the same time, the economies of developed countries have also changed significantly. Over the last decade, everything has become cheaper: computers, telephony, data services. Significant arrays of services, such as social networks, search engines, cloud services, e-mail, text messages become free. The growth of the creative nature of the economy has led to the greatest change in recent decades: consumption has largely become a direct investment in human capital if it is used in an ever-widening range of activities. Thus, the information economy based on the modern financial system today looks much more stable and self-sufficient than ever before.

In our opinion, this indicates not just significant changes, but a qualitatively new nature of the organization of financial systems of developed countries, a new state of their stability, more precisely a new understanding of such a state, when the implementation of new financial technologies based on digitalization, financial systems organizationally and functionally able to 'pass' large amounts of additional liquidity through the economy without significant macroeconomic negativity. Moreover, FinTech is today the largest driver of constant transformations of financial and, behind them, economic systems in general, both nationally and globally.

All the above necessarily actualizes the development of the FinTech sector, analysis of new trends in the activities of financial institutions related to the implementation of new financial technologies based on the digitalization of the economy.

Analysis of the recent studies and publications that have initiated the solution of this problem, definition of the unresearched part of the paper's general problem. Theoretical aspects of the formation and functioning of financial technologies are studied in the works of J. Barberis and S. Chishti [1], H.T. Karcheva [5], V.V. Kovalenko [6], L.V. Zherdetska [13], H.M. Pochenchuk [9], A.V. Ryabova [10], D.Ye. Tretyakov [11] and other scientists. However, these studies are more concerned with the impact of financial technology exclusively on the banking system, ignoring the activities of the non-banking sector of FinTech companies, which was developed in Ukraine, but also received a number of problems that need to be diagnosed and suggested solutions, including ways of interaction between banks and FinTech companies in Ukraine.

The formulation of the paper's objective. The purpose of the article is to analyze the current market of FinTech services in Ukraine, the problems of formation and development of existing FinTech companies, commercial banks in their 'connections' with the FinTech industry, as well as problems of interaction between both sectors in the single domestic financial services market.

Presentation of the basic material of the study with justification of the obtained scientific results. Today, more than 100 companies operate in the field of financial technologies in Ukraine, most of which have started operating in the last five years. The most popular areas of work are payments and mobile wallets. Such data are given in the Ukrainian Fintech Catalog-2019, the publication of which was prepared by the Ukrainian Association of Fintech and Innovative Companies together with the technological payment company Visa and the NBU. Today, this publication is essentially the calling card of the domestic FinTech market for communication between its participants and foreign colleagues and partners, government officials and investors. Ukrainian Fintech Catalog-2019 (UFTC) is not only a study of the Ukrainian financial technology market, but also an analysis of trends in this market. In addition, it is a kind of map of the domestic Fintech ecosystem and a catalog of companies (with questionnaires) operating in this market in Ukraine. Thus, according to the information in the Ukrainian Fintech Catalog-2019, 63\% of Ukrainian Fintech companies are financed exclusively at their own expense and the same number have passed the break-even point. At the same time, 14\% of companies have a staff of more than 75 people. $43 \%$ of Ukrainian FinTech companies conquer the international market. And of those who work exclusively in Ukraine, $73 \%$ are later going to start working abroad [8].

Today, FinTech is one of the main drivers of the digital transformation of the financial sector and increasing financial inclusion. Analyzing the catalog, we can say that the Ukrainian FinTech market is actively developing, which means that the country is moving in the right direction - to simpler and more affordable financial services, a transparent economy and attracting more people to the modern financial system. Technology enables financial service providers to reduce costs and gain remote access to consumers, leading to greater financial inclusion. Technology also opens the door to the financial services market for new players: mobile operators, ecommerce platforms, messengers, social networks and other technology giants with a large customer base.

In mature markets, where traditional financial services are more developed, new players have less influence. However, today the variety of offers of new financial services is simply impressive. Regulators around 
the world have become aware of the need to support new financial technologies through new regulation, the creation of 'sandboxes' (regulatory test environments), the introduction of a 'flexible approach to licensing' for new market participants, and tax benefits. In this respect, the United Kingdom, the Nordic countries, Lithuania and Singapore are the best examples of supporting new technologies.

According to experts in this field, Ukraine is lagging behind, it needs to make up for lost time. Most FinTech startups in the country are heavily dependent on equity because there is no functioning capital market to which they can turn. The infrastructure of electronic financial services remains imperfect, and financial institutions need to invest in technology.

Today, it is also necessary to change outdated domestic legislation to stimulate the creation of a favorable environment for the development of entrepreneurship in the field of electronic finance. Regulatory 'sandboxes' are the 'cribs' of FinTech, and Ukrainian regulators should help ensure that the Ukrainian FinTech industry can use this tool. Thus, rapid technological progress is changing the financial services sector around the world. Fintechservices were once considered a skillful addition to existing traditional services to make the work and activities of customers more comfortable. But now these services are challenging all aspects of the financial world from all possible points of view.

In its own study, the Global FinTech Adoption Index 2019 EY identifies two types of FinTech proposals: 'transformed' (disrupted) and 'discovered' (invented) [4]. The transformed service is one that has historically been offered by traditional players. For example, car insurance or currency trading. Fintech providers use technology to transform these services by offering consumers a more attractive offer, such as more features, more convenience, lower rates and commissions. This significantly changes customer expectations, encouraging 'old-timers' in the market to develop similar services to remain competitive and maintain their market share.

The invented service is a service that did not exist before, but it has become possible now, thanks to technology and alternative business models, such as equal credit (P2P) or mobile payments. Some invented services fill niches in the market, while others have the potential to rethink and transform entire financial sub-sectors.

The fintech industry began to grow rapidly. This sector no longer belongs only to startups: traditional market players assert themselves both through their own developed services and through the rapid M\&A activities in the FinTech industry. Interestingly, according to the EY Global FinTech Adoption Index 2019, large developing countries lead the ranking of the level of use of FinTech by consumers, in China, India, Russia and South Africa, this figure is over $80 \%$. At the same time, these figures in Canada, the United States, France and Japan do not exceed $50 \%$ [4].

Globally, most consumer FinTech services are concentrated in only five areas: remittances and payments, budgeting and financial planning, savings and investments, borrowing and insurance. Remittances and payments are the most common financial directions.

In recent years, traditional players have focused their breakthrough FinTech services in areas such as online currency exchange, online investment and management consulting, and global trends are also driving digital banking without physical branches. At the same time, consumer-oriented technology companies are not limited by 'direct active interaction' solutions. For example, insurance-related technologies include technology-assisting projects, such as equipping cars with telematics modules to transmit information to car insurers, or mobile fitness apps connected to health insurance companies that count steps and other movements and offer performance-based insurance discounts.

Fintech does not always mean deep technology (Deep Tech). Some of the best neobanks and remittance projects in the world are based on the principle of 'less technology, more attention to users'. They strengthen service targeting and personalization, analyze user behavior to optimize online and offline work, improve experience in areas such as price, convenience, access, and more. Their appeal lies in a customer-oriented approach, reviewing and simplifying various processes for customers: from concluding a deal to daily maintenance. At the same time, technologies, against the background of the inflow of investment in the industry, expand the limits of what is possible in all directions.

The classic banking world has already realized that while its traditional middle-aged and older audience may prefer offline communication, the younger generation of consumers and corporations is looking for much more flexible options that will save them time and allow them to choose channels and ways to communicate with their suppliers of financial services. Investors also understand this and expect classic players in the financial sector to incorporate digital banking into their strategic plans. Some decide to launch their own digital services, others rely on the model of partner banks and the release of APIs, which third-party FinTech suppliers can use to create unique solutions.

A significant technological trend is gaining momentum - the introduction of multi-channel banking, whereby which the user through the website can initiate support of the financial service provider, continue in any popular messenger and complete by concluding a remote service agreement - customer-bank. Data between channels is seamlessly synchronized to provide the user with a presence effect.

According to Econsultancy and Adobe's 2018 Digital Trends in Financial Services report by Econsultancy / Adobe, nearly $20 \%$ of financial service providers worldwide already use artificial intelligence (AI) in their operations, while $41 \%$ plan to implement it soon. Cleverly designed AI applications are able to simplify daily internal operations by automating repetitive tasks and provide strong support for user targeting, forecasting the actions and financial condition of the client and risk management [13]. 
AI-based big data analytics provides large financial service providers with unprecedented opportunities to respond to real-time consumer and economic trends. AI-based compliance automation systems dramatically reduce the cost of inflated legal departments and risk departments, as well as reduce the percentage of human error.

Open banking as a trend is a necessary prerequisite for the mass expansion of digital banking approaches. Open banking allows you to create APIs with automatic settings, which third-party developers can apply to use open financial data provided by banks. User data from various sources becomes easily available for use and analysis through a single standardized API. This benefits both service providers and consumers by increasing transparency and reducing the risks of customer analysis and leads to improved conditions for the use of services for consumers and reduced losses for suppliers.

The world's leading suppliers of the financial sector already use 'cloud' SaaS solutions for a number of internal functions, such as accounting, CRM and HR. 'Cloud' KYC-functionality and security check function by third-party suppliers are also constantly gaining popularity. Investments in 'cloud' infrastructure and data storage and processing are becoming a core element in the overall IT budgets of major financial service providers.

An equally important trend is solving the problem of people who do not have bank accounts. According to the World Bank in 2017, more than 1.7 billion people worldwide were identified as unbanked - that is, without an official account with a financial institution or through a mobile provider. The task of reaching this huge number of people with financial services remains one of the top priorities of financial service providers around the world. And here technologies begin to work.

In our opinion, the defining characteristics of the participants of the modern fintech market in Ukraine are the following: 1) these are organizations that develop and sell their own innovative fintech mono-service or product (ie companies that focus on only one service or one product); 2) these are software development companies that develop and sell their own various fintech services or products; 3) these are organizations that use fully developed services or products and have income.

The Ukrainian fintech catalog 2019 includes (again) more than 100 companies participating in the Ukrainian fintech market. The companies included in the catalog can be generally divided into service providers, infrastructure providers (enablers), developers of multi-product and non-financial solutions. Most UFTC fintech companies provide B2B services or products [3]. This contradicts the global trends in the use of fintech technologies, where the corporate acceptance of fintech services lags far behind the acceptance by consumers. We explain the large number of B2B projects by a number of factors, including: weak dynamics of household income in Ukraine, which limits the growth potential of B2C-focused organizations; lack of financial sector infrastructure for the general population, especially in small towns and villages; 'crisis of confidence' of Ukrainians in financial services, which arose after the liquidation of many banks. Compared to B2B solutions, the development of B2C proposals requires significant investment in large-scale marketing, which most fintech projects can not afford for the most part due to lack of capital.

Funding remains a sore point for companies involved in new technologies in Ukraine. Much of it is fully funded by our own savings, although new technology projects around the world are usually funded by outside capital. However, in Ukraine, as already mentioned, $67 \%$ of fintech companies are fully financed from their own sources. This indicates a general lack of external capital for development, which slows down the development of the sector and prevents rapid expansion. Foreign investors are very cautious and none of the traditional commercial banks offer significant lending programs and conditions for high-tech growing businesses.

In contrast to the global trend, when $80 \%$ of banks and other traditional financial services providers plan to purchase or finance financial solutions to expand and improve their own service offerings, the Ukrainian financial market is largely independent of the influence or financing of the traditional banking sector. Ukrainian banks are probably aimed at continuing to operate in the traditional offline environment or through their own solutions and selective cooperation with third-party service providers. Thus, if we summarize the characteristics of fintech organizations in the national market, we get a kind of collective image of the average Ukrainian fintech company, which: is focused on national and European markets; has no investments from banks; top management has experience in traditional financial services; is focused on B2B; is self-financed; has been operating for more than 3 years and is still under development.

Among the top 5 services / solutions provided by fintech companies in Ukraine on B2B and B2C models are the following (fig. 1): 


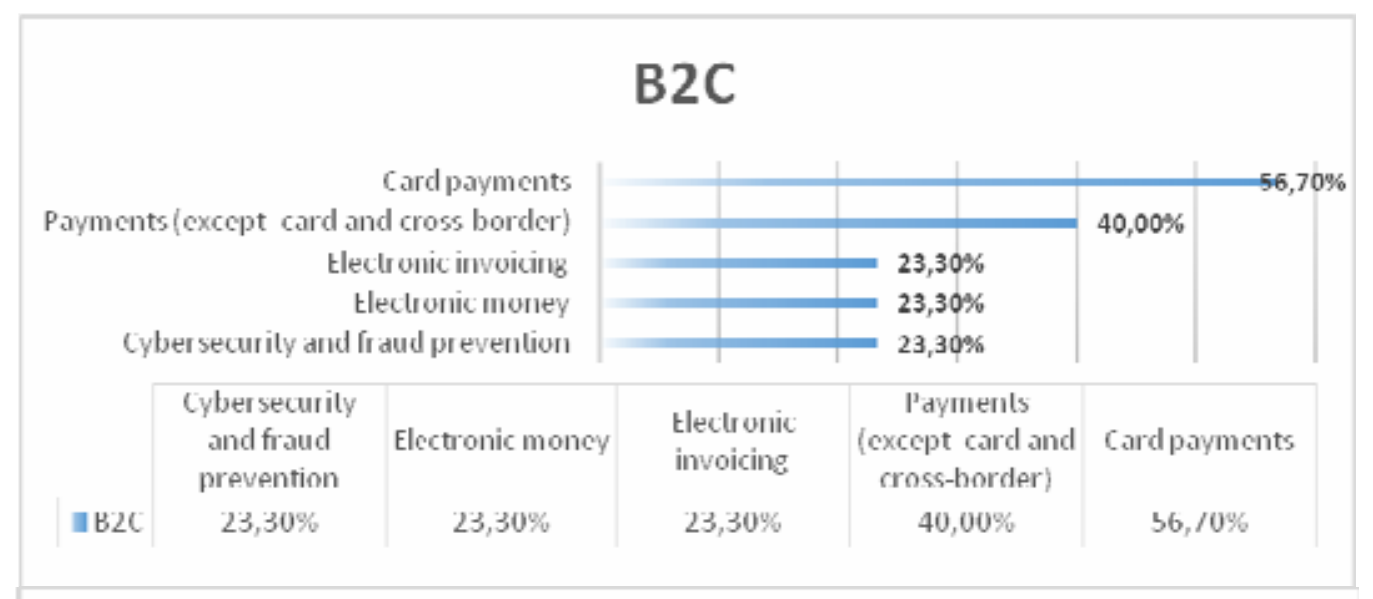

B2B

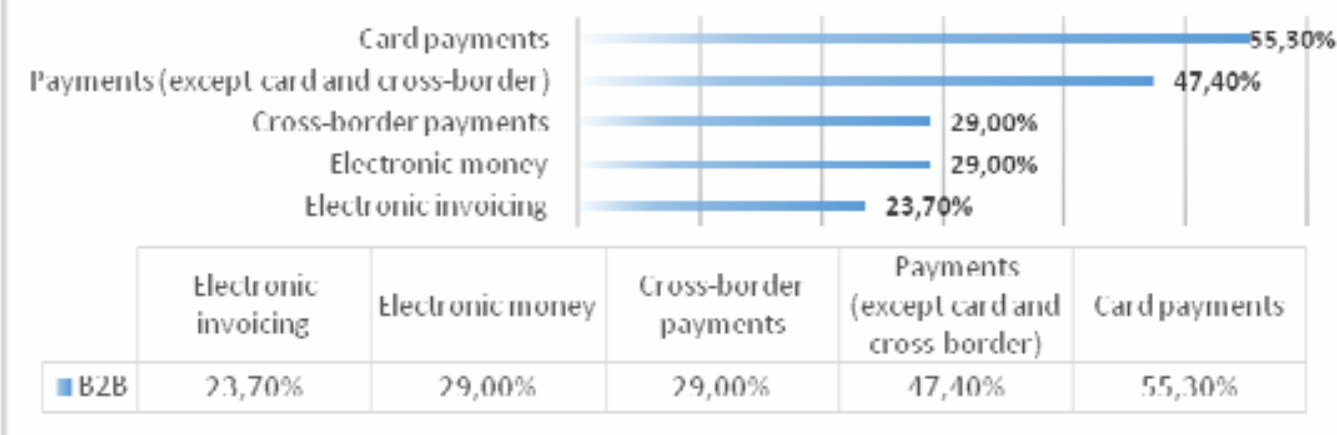

Fig. 1. Areas of services of fintech companies of Ukraine Source: [8]

Among both business models, the most popular services are card payments and other types of payments (except for card and cross-border payments). Other services that are present in both business models: electronic invoicing and electronic money. The least popular fintech offers are depository services and asset and investment management. Each of them is provided by only one company from UFTC.

The catalog also includes companies operating in relatively new or uncommon for the Ukrainian market financial sectors. In particular, InsurTech, RegTech (including compliance automation), AI / data analysis and crowdfunding subsectors. Although each of these industries has more than one company, the total number is small compared to mass market-oriented services.

The variety of payment and e-invoicing solutions demonstrates that the ecosystem responds to the basic demands of the mass market for faster and more flexible money transfers, utility bills and retail decisions. This is 'easy money' for project founders compared to more sophisticated services and solutions that require significantly more investment in R\&D and outreach to potential customers. The lack of decisions on investment management, storage and management of personal finances clearly indicates the lack of maturity of the overall ecosystem compared to major global markets. This is primarily due to the basic level of the capital market in Ukraine and the lack of access to it.

In operating activities, the most common way to monetize fintech companies is a transaction fee: most companies use this approach. Payment for the period of use is another popular model. At the same time, companies use a combination of several monetization mechanisms for different customers. However, for those who provide services and solutions to banks, the importance of payment mechanisms for the period of use and distribution of income is much more important. Transaction fee is applied by $68.4 \%$, payment for the period of use $-63.2 \%$, and income distribution $-57.9 \%$ of companies cooperating with banks [3].

Given the general small number of financial organizations operating in Ukraine, the 'number of competitors' is expected. Obstacles to the entry of new projects into the market are very significant, given the lack of capital and difficulties in convincing customers to start using new services from new companies with an unproven reputation. However, the current positive sentiment about 'global competitiveness' is a manifestation of selfconfidence and a lack of realistic understanding of what the world markets have to offer, especially against the background of more than $40 \%$ of UFTC companies that say they operate only in Ukraine. This 'technological arrogance' may be one of the reasons why investors neglect many fintech projects of Ukrainian origin.

Ukraine is characterized by a very low level of participation of banks in the capital of fintech companies in combination with the lack of experience in the fintech industry or digital strategy at the board level, which 
contradicts the global trend of banks to make fintech decisions. Ukrainian banks do not seem to perceive fintech or digital transformation as new opportunities, but as too expensive 'toys'.

In general, if we generalize the characteristics of Ukrainian commercial banks in terms of 'connections' with the fintech industry, its (bank's) kind of collective image is as follows: it has no share in the capital of thirdparty fintech companies; it has limited experience and understanding of the fintech industry at the board level; it is a universal bank; it has specialists responsible for working with third-party software developers. Only some banks provide deposits and other products remotely. Other digital services they offer include payments for utilities and other online banking services for individuals, online contracts, currency exchange in online banking for individuals and direct payments from a bank account in online stores.

Commercial banks in Ukraine are generally driven by mass market demand when developing and launching digital services for their customers. Thus, the most popular digital / remote services that banks offer to their retail customers and small and medium-sized businesses are focused on the daily needs of the target audience.

It is clear that most banks invest in strategy, business process development and planning, as well as in selfmaintenance of existing and development of new hardware infrastructure. Global data on the distribution of IT budgets between maintaining outdated systems and investing in new capabilities is difficult to find, but most IT work is done with banks' internal resources, especially in improving strategy and planning, an area that typically operates through a third-party vendor. The global banking system is progressively engaging outsourcing to reduce costs and increase experience. However, Ukrainian banks perform this work independently, which is more likely due to lower labor costs compared to paying for third-party services.

Internal modernization or upgrades in the banking system focus mainly on the following areas: cybersecurity, mandatory reporting and compliance, acceptance of applications for financial products through electronic channels, data analysis to prevent fraud, management accounting and data analysis to help increase sales. Investments in these categories were or are planned in the near future in more than $70 \%$ of Ukrainian banks [8].

In recent years, cybersecurity, mandatory reporting, and compliance, along with data analytics, have remained top priorities. Despite bureaucratization, traditional commercial banks are facing the realization that the digital age has come and they need to adapt and keep up with trends.

In Ukraine, there is a difference between the attitudes of fintech companies and banks, as well as between their plans for digitalization, although they are all part of the same market for Ukrainian financial services. This can be partly explained by the fact that a large number of financial organizations operate both in Ukraine and abroad, and are influenced by global market change factors that are not so acute in Ukraine.

It is important that both fintech companies and banks perceive the need to provide remote customer identification as the most important legislative change needed given the current market demand. This indicates, at least in part, that banks are forced to adjust their supply to the growing demand for mobile banking and consider it a necessary competitive factor. Both groups also prioritize improving cybersecurity processes in banks and analysts to prevent fraud. However, perhaps the most important thing is that both fintech companies and banks see great potential in future projects focused on financial services for those who do not have bank accounts - a lucrative niche for new fintech proposals from both independent actors and classic market players.

The findings of the study and the prospects for further researches. Thus, in Ukraine, full-fledged interaction between traditional representatives of the banking sector and flexible fintech companies is obviously still far away, but the reasons for this must be sought in both sectors. If we take the banking system, historically almost none of the Ukrainian banks was created as a banking business, and traditional operating models are known to be difficult to transform. As a result, the old is still wary of the new. On the other hand, Ukrainian fintech companies look like modern and very interesting 'products' of the market. Given the territory of the country and the population, one could expect a much larger number of projects operating in the market and a significant attention to the client audience. However, there are about 100 projects, including infrastructure developers, and most of them are focused on the corporate market. This situation is due to a number of factors: general distrust of financial services combined with lack of financial literacy, lack of capital for development, reluctance of traditional banks and private corporations to use these new technologies and approaches, and almost complete lack of capital markets in the country. In total, this is characterized as a 'weak domestic market'.

With weak demand and disposable income within the country, it is known that it is difficult to test business models and start earning. Such startups are forced to test their strength in foreign markets. However, penetrating these markets without a proven home business case and extremely limited funding for marketing processes is equally difficult. Significant marketing costs mean the need for third-party investment capital, but investors do not seek to invest in unproven business models. Only a small number of entrepreneurs can move out of this vicious circle, moving through a combination of self-financing, progressive customer-oriented thinking and simple luck.

Given these unfavorable market conditions, we believe that the number of fintech players in the market (albeit small in absolute terms) and the speed of their scaling should be seen as a definite victory and a clear path in the right direction.

Reforming the regulatory framework is also critical in many areas, the main ones being:1) implementation of the Second EU Payment Directive as absolutely necessary to provide a legal and technological framework for a number of financial services that do not exist in Ukraine; 2) regulatory framework, the 'sandbox' approach is a great way to stimulate the rapid development of fintech projects, reducing the risk of violations of the law and ensuring the verification of business models; 3) access to capital, as the development of the financial sector is in dire need of 
external sources of funding, the lack of which is caused by imperfect protection of intellectual property rights and the risks of the judiciary; 4) the market for crypto and alternative currencies is still a challenge even for developed markets, but the legal framework is needed to bring numerous crypto infrastructure projects into the legal field and to enable them to interact with traditional financial service providers.

Equally important is the continuous work of all stakeholders to find common ground and share knowledge. Banks need to face the realities of the digital age and build long-term technology-oriented strategies, even if this means reducing margins in the short term. Fintech companies must stop overestimating themselves and start sharing experiences with the 'old-timers' of the market. In this case, both camps will benefit from mutual support. At present, market growth is less dependent on competition and more on raising awareness of the problems and technologies that can solve them.

With improved access to capital, stabilization of the economy, updating of the legal framework and more traditional players in the financial services market using new technologies, Ukraine is likely to experience rapid growth in a sector that already outperforms any other high-tech industry in the domestic market.

\section{References.}

1. Chishti, S. and Barberis, J. (2016), "The FinTech Book: The Financial Technology Handbook for Investors, Entrepreneurs and Visionaries", Journal of Indonesian Economy and Business, vol. 31, no. 3, pp. 348348.

2. Dudynets, L.A. (2018), "Development of financial technologies as a factor of financial system modernization", Hlobalni ta natsionalni problemy ekonomiky, vol. 22, pp. 794-798.

3. Catalog of FinTech companies of Ukraine 2019, "Fintech-2019: a study of the Ukrainian financial technology market", available at: http://www.management.com.ua/tend/tend1139.html (Accessed 2 July 2020).

4. Global FinTech Adooption Index 2019, available at: file://C:/Users/Mothes\%20Since/Downloads/eyglobal-fintech-adoption-index-2019.pdf (Accessed 2 July 2020).

5. Karcheva, H.T., Lernatovych, R.M. and Kavetskyi V.V. (2017), "The use of blockchain technologies as a factor in improving the efficiency of the financial sector", Bankivska sprava, no. 2, pp. 110-119.

6. Kovalenko, V.V. (2018), "Fintech Development: Threats and Prospects for Ukrainian Banks", Pryazovskyi ekonomichnyi visnyk, vol. 4 (09), pp. 127-132.

7. Nikiforov P., Babukh I. and Kinashchuk S. (2020), "FinTech as a driver for today's financial market transformations: the Ukrainian context”, Prychornomorski ekonomichni studii, vol. 51, pp. 189-194.

8. USAID Financial Sector Transformation Project, "Survey of Ukrainian banks and fintech companies 2019”, available at: http://www.fst-ua.info/wpcontent/uploads/2019/-12/FinTech-Survey-Report_-UKR_12-122019.pdf (accessed 3 July 2020).

9. Pochenchuk, G.M. (2017), "Financial technologies development and regulation”, Ekonomika i supilstvo, vol. 13, pp. 1193-1120.

10. Ryabova, A.V. (2015), Emerging FinTech market: types and features of new financial technologies. Journal of Economics and Social Sciences, no 7, 4 p.

11. Tretiakov, D.E. (2017), "Trends in the development of the banking and financial-technological sector based on the basis of the application of high technologies", Kreatyvna ekonomika, vol. 11, no. 8, pp. 893-898.

12. Zherdetska, L.V. and Horodynsky, D.I. (2017), "Development of financial technologies: threats and opportunities for banks", Ekonomika i supilstvo, no.10, pp. 583-588.

13. 2018 Digital Trends in Financial Services. Digital Intelligence Briefing, available, at: https://wwwimages2.adobe.com/content/dam/acom/uk/moda-loffers/pdfs-/Econsultancy-2018-Digital-TrendsFS_EMEA.pdf (Accessed 3 July 2020).

Стаття надійшла до редакиії 17.08 .2020 р. 